\title{
Transformacje życia profesjonalnego asystentów rodziny: komunikowanie doświadczeń
}

\begin{abstract}
Abstrakt
Przedmiotem przeprowadzonych badań były doświadczane transformacje życia profesjonalnego ujawnione w komunikacji asystentów rodziny. Efektem tej komunikacji są zapisy wypowiedzi, które poddano konceptualizacji w oparciu o podejście transwersalnej analizy aktywności - holistyczne ujmowanie aktywności profesjonalnych i spoglądanie na nie przez pryzmat procesów transformacji, jakie nieustannie się w nich dokonują. Wypowiedzi asystentów skonceptualizowano pod kątem zidentyfikowania modyfikacji procesów transformacji życia profesjonalnego, na które one wskazywały. W rezultacie interpretacji wyłoniono styl komunikowania doświadczenia profesjonalnego. Tekst sugeruje możliwość wykorzystania potencjału interpretacji, jaki można wydobyć z komunikacji o zmianach zachodzących w życiu profesjonalnym, w procesie stymulowania refleksji podmiotu działającego.
\end{abstract}

Słowa kluczowe: transwersalna analiza aktywności, komunikowanie doświadczenia, paradygmat transformacji, modyfikacje procesów transformacji życia profesjonalnego, styl komunikowania doświadczenia profesjonalnego.

\section{Transformations of Child Protection Workers' Professional Life: Communicating Experiences}

\begin{abstract}
The research subject was the experienced transformations of professional life revealed in the communication of child protection workers. The result of this communication are transcripts of expressions that have been conceptualized based on the approach of the transversal analysis of the activity - the holistic approach to
\end{abstract}

\footnotetext{
* Uniwersytet Łódzki.

Artykuł otrzymano: 2.02.2021; akceptacja: 11.03.2021.
} 
professional activities that looks at them through the prism of the transformation processes constantly taking place in them. The expressions of the child protection workers were conceptualized in terms of identifying modifications in transformation processes in professional life. As a result of the interpretation, the style of communicating professional experience emerged. The paper suggests the possibility of using the potential of interpretation that can be extracted from communication about changes in professional life in the process of stimulating the reflection of the acting entity.

Keywords: transversal analysis of the activity, communication of experience, the paradigm of transformation, modifications of the transformation processes in professional life, the style of communicating professional experience.

\section{Wstęp}

Życie profesjonalne ${ }^{1}$ można postrzegać jako aktywność wielokrotnie złożoną, podlegającą permanentnym transformacjom, jako proces, w którym i dzięki któremu realizowana jest aktywność profesjonalna jednostki (por. Marynowicz-Hetka 2018: 10). Z tego punktu widzenia istotne wydaje się komunikowanie doświadczenia profesjonalnego, w którym uwidacznia się propozycja znaczeń, jakie podmiot przekazuje na temat swoich aktywności profesjonalnych będących $\mathrm{w}$ procesie transformacji. Uchwycenie tych znaczeń może oznaczać konceptualizację zorientowaną na zobrazowanie tego, w jaki sposób działający identyfikuje transformacje, w których uczestniczy, oraz zrozumienie tych identyfikacji.

Przedmiotem namysłu badawczego były doświadczane transformacje życia profesjonalnego ujawnione w komunikacji asystentów rodziny (praktyków pracy socjalnej z rodzinami wieloproblemowymi). Efektem tej komunikacji stały się wypowiedzi asystentów, które zostały wywołane pod wpływem prośby, by zabrali głos na temat procesu przemian zachodzących w ich życiu profesjonalnym. Interpretacja wypowiedzi asystentów była prowadzona w celu zrozumienia, jakie transformacje asystenci identyfikują oraz w jakim stylu je komunikują.

Prezentowana interpretacja zapisów wypowiedzi asystentów jest pretekstem do rozpoczęcia namysłu nad praktycznym zastosowaniem potencjału interpretacji, jaki można wydobyć z komunikacji o zmianach zachodzących w życiu profesjonalnym, w procesie stymulowania refleksji podmiotu działającego.

\footnotetext{
1 Życie profesjonalne jest rozumiane jako „transformacja aktywności i podmiotu usytuowanego w niej” (Barbier 2016: 258). Tak rozumiane życie profesjonalne sprawia, że możemy mówić o procesie transformacji, w którym i dzięki któremu realizowana jest aktywność profesjonalna podmiotu i jej trwanie (por. Marynowicz-Hetka 2018: 10). Interesujące wydaje się to, w jaki sposób podmiot działający doświadcza tej transformacji i jak to wyraża poprzez komunikację.
} 


\section{Materiał badawczy}

Materiał empiryczny zawiera wypowiedzi asystentów, które stanowią wyrazy komunikowania doświadczenia z pola praktyki. Korpus tych materiałów składa się z trzech wywiadów zbliżonych w swoim przebiegu do wywiadów narracyjnych (por. Schütze 1977), które były zogniskowane wokół wywołania refleksji asystentów nad procesem zmian zachodzących w ich życiu zawodowym. Wypowiedzi asystentów zostały wywołane pod wpływem następującej prośby badaczki:

Interesują mnie Pani/Pana refleksje na temat tego co się zmienia, zmieniło w Państwa doświadczeniu profesjonalnym, w Państwa pracy, w rodzinach, z którymi Państwo pracowali lub pracujecie nadal. Ogólnie wszystko co jest związane z transformacją, procesem zmian zachodzących w Państwa aktywności, odczuciach, doświadczeniach, refleksjach etc. Czas i konkretne treści, o których Państwo opowiedzą zależą tylko od was.

Osoby, które zechciały wziąć udział w wywiadzie, były wcześniej uczestnikami warsztatów skoncentrowanych na analizie własnej praktyki profesjonalnej2. Narratorzy deklarowali intencję doskonalenia profesjonalnego poprzez autoanalizę podejmowanej aktywności profesjonalnej i wyrażali chęć podzielenia się swoją refleksją z innymi.

Narratorzy, którzy wzięli udział w badaniu, to dwie kobiety i jeden mężczyzna pracujący jako asystenci rodziny na terenie wiejskim i małego miasta.

Asystentka (A1) pracuje jako asystent rodziny od 2018 r., wcześniej była zatrudniona jako wychowawca $\mathrm{w}$ areszcie śledczym i prowadziła własną działalność gospodarczą, niezwiązaną z działalnością pedagogiczną. Ukończyła pedagogikę resocjalizacyjną i opiekuńczo-wychowawczą oraz studia podyplomowe z mediacji sądowej i pozasądowej.

Asystent (A2) jest związany z asystenturą od 2010 r., pracuje jako asystent rodziny od roku 2014, wcześniej pełnił funkcję wychowawcy i pedagoga w ochotniczym hufcu pracy. Ukończył studia pedagogiczne na dwóch specjalnościach: resocjalizacja i aktywizacja zawodowa oraz pedagogika opiekuńczo-wychowawcza. Ukończył roczny kurs dla terapeutów uzależnień oraz następny kierunek studiów - administracja europejska, oraz przed laty studiował psychologię.

Asystentka (A3) zajmuje się asystenturą rodzinną od 2017 r., wcześniej przez wiele lat była zatrudniona jako krawcowa. Ukończyła studia licencjackie na kierunku praca socjalna.

\footnotetext{
2 W ramach IX Ogólnopolskiego e-Zlotu Asystentów Rodziny, połączonego z konferencją naukową zatytułowaną - Między wsparciem rodziny a ochrona dziecka przed krzywdzeniem - rola, zadania dylematy etyczne asystentów rodziny (24.-26.09.2020), prowadziłam webinar - Refleksyjny praktyk - doskonalenie poprzez analizę praktyki profesjonalnej. Troje uczestników tego webinaru zechciało wziąć udział w wywiadzie i szerzej podzielić się ze mną swoim doświadczeniem profesjonalnym. Wywiady były prowadzone i rejestrowane przez Microsoft TEAMS.
} 


\section{Podejście do badania}

Ramą teoretyczną dla zastosowanego podejścia badawczego jest transwersalna analiza aktywności (TAA), rozwijana przez Jean-Marie Barbiera (2016). Przy czym samo podejście badawcze jest tu rozumiane jako sposób epistemologicznego poznania, stwarzający specyficzną przestrzeń do interakcji z tekstem, niosącym ze sobą określone znaczenia, z których badacz - wnikliwy czytelnik i interpretator, wydobywa własny sens ${ }^{3}$. W sukurs temu pomysłowi idzie rozpoznanie kategorii węzłowych, stanowiących elementy konstytutywne owego podejścia badawczego, są to: (1) intencja- (2) kom unikowanie doświadczenia-(3) kon ceptualizacja.

(1) Intencje ujawniają się w czynie, stopniowo uświadamiają podmiotowi, czego on szuka (tamże: 89). W przypadku obranego podejścia badawczego początkowo chodziło o to, by stworzyć interpretację wypowiedzi asystentów, która w pewnym stopniu mogłaby korespondować z założeniem, że są oni, w mniej lub bardziej świadomy sposób, uczestnikami procesu transformacji ich życia profesjonalnego, w którym następuje nieustanny ruch, zmiana, przekształcenie. Ta teza odwołuje się do myślenia o aktywności opartego o paradygmat transformacji (por. tamże: 229; Barbier, Durand 2018). Pojawiła się ciekawość tego, w jaki sposób asystenci są w stanie komunikować, porządkować doświadczenie związane z uczestniczeniem $\mathrm{w}$ procesach transformacji życia profesjonalnego i jaki rodzaj stylu komunikacji wybiorą, by skonstruować wypowiedź na ten temat. Towarzyszyło temu odczuciu oczekiwanie związane z odkryciem narracji, w której narrator

\footnotetext{
${ }^{3}$ Z perspektywy transwersalnej analizy aktywności istnieje różnica pomiędzy sensem i znaczeniem. Sens przynależy do przestrzeni aktywności mentalnej, która zachodzi w procesie doświadczenia/dialogu wewnętrznego podmiotu (Barbier 2016: 204-205), natomiast znaczenie jest elementem aktywności komunikacyjnej adresowanej do odbiorcy, która zawiera określoną intencję wytworzenia u niego efektu sensu (tamże: 255). Aktywność komunikacyjna, poprzez którą przekazywane są znaczenia, jest powiązana z procesem konstruowania sensu. Zjawiska sensu i znaczenia przynależą do sfer aktywności komunikacyjnej i mentalnej, które są ze sobą związane, ale zachowują pewną autonomię funkcjonowania, wymagającą specyficznych narzędzi analizy (por. Barbier 2006: 178). Jakość tego związku można charakteryzować poprzez efekt sensu, który oznacza to, co robię z komunikatem, który przekazuje znaczenie. Podejście TAA uwrażliwia na dynamiczne związki pomiędzy intencją przekazania określonego znaczenia a recepcją znaczącego komunikatu przez Drugiego, który może wytworzyć w związku z nim sens, niekiedy nawet sprzeczny z tą intencją. Dyskurs TAA wpisuje się w szersze rozważania filozofii języka, które biorą pod uwagę zarówno charakter społeczny, jak i indywidualny zjawisk dyskursywnych. Barbier odwołuje się, między innymi, do rozważań Bertranda Russela, Charlesa Sandersa Peirce'a, Michaiła Bachtina, Johna Searle’a oraz Edmunda Husserla (2006: 182-187).

Przyjęte rozróżnienie sensu i znaczenia implikuje następujące wnioski dla epistemologii poznania naukowego: (1) badacz ma jedynie pośredni dostęp do zjawiska konstruowania sensu, w odróżnieniu od podmiotu komunikującego (tamże: 185), jednocześnie konstruuje konceptualizację w oparciu o sens, który nadaje doświadczeniu komunikowanemu przez ten podmiot; (2) badacz przekazuje znaczenia płynące ze skonstruowanej konceptualizacji doświadczenia komunikowanego, mogące wpływać na procesy nadawania sensu u odbiorców tych komunikatów. Z tej perspektywy interesującym sposobem analizy jest wspólne konstruowanie przez badacza i badanego znaczeń i ich interpretacji, które tworzą się w oparciu o przedmiot analizy (tamże: 189).
} 
rekonstruuje przemianę siebie jako podmiotu profesjonalnego, co można nazwać narracją transformacyjną (quest narration) (por. Ulatowska 2014). Tymczasem w procesie odkrywania sensu, jaki był wydobywany z wypowiedzi asystentów, okazywało się, że przedmiotem ich komunikacji nie jest rekonstrukcja przemiany profesjonalnej, o której chcą opowiedzieć, ale raczej dostrzegalne przez nich modyfikacje, będące widocznym efektem procesów transformacji lub też dynamizujące owe procesy, w których uczestniczą. Odkrycie badawcze pociągnęło za sobą przemianę intencji poszukiwań interpretacyjnych, którą stało się zidentyfikowanie modyfikacji procesów zmian, o których opowiadali asystenci, oraz wyodrębnienie i scharakteryzowanie momentów aktywności znaczących dla dynamiki tychże procesów transformacji.

(2) Wypowiedzi asystentów były traktowane jako przejaw komunikowania doświadczenia profesjonalnego. Zawierały one propozycje znaczeniowe związane z identyfikowaniem doświadczanych transformacji (por. Barbier 2020: 228). Istotna okazała się koncentracja na modyfikacjach dostrzegalnych w życiu profesjonalnym - sobie samym jako podmiocie działającym i realizowanej aktywności. Asystenci w swojej komunikacji ujawniali uświadomione zmiany, jakie zaszły w ich zaangażowaniu się w aktywność profesjonalną. Tego rodzaju fragmenty wypowiedzi asystentów były wybierane do interpretacji. Jednak współistniały one w szerszej narracji dotyczącej również przemian dostrzegalnych w innych, na przykład członkach rodziny czy organizacji instytucjonalnej pomocy społecznej.

Asystenci komunikowali doświadczenie profesjonalne w formie narracji (por. Barbier 2016: 105). Kluczowa dla interpretacji wypowiedzi asystentów, z punktu widzenia paradygmatu transformacji, stała się cecha ich narracji, czyli retrospektywność. Ujawniała się ona poprzez unaocznienie dostrzeżonych zmian ${ }^{4}$, zachodzących $\mathrm{w}$ jednostkowym zaangażowaniu się w aktywność profesjonalną przez temporalne rozróżnienie na „dzisiaj” i „wczoraj”, które świadczy o przeciwstawieniu temu, co było, tego, co jest obecnie, co stanowi odmienną jakość w stosunku do przeszłego podmiotowego angażowania się w aktywność (por. Gülich 1984: 250).

(3) Dokonywano konceptualizacji wypowiedzi asystentów przy użyciu pojęć TAA, ale bez potrzeby zachowania puryzmu w ich stosowaniu, co sprawia, że stosowany repertuar pojęciowy niekiedy wykracza poza siatkę pojęciową transwersalnej analizy aktywności. Chodziło o znajdywanie pojęć, które spełnią funkcję ekranów poznawczych (Witkowski 2020: 4), za pomocą których osiągalna stanie się pojmowalność wypowiedzi asystentów w związku z ich uczestnictwem w procesach transformacji życia profesjonalnego. Przy czym należy tutaj podkreślić, że chodzi o pojmowalność pozwalającą wyjść poza dosłowność wypowiedzi, która niczym kubistyczny obraz - jednocześnie pokazujący ten sam przedmiot

\footnotetext{
4 Przy czym nie chodzi tu o wariant, w którym narrator rekonstruuje drogędojścia/wyjścia/przejścia/przezwyciężenia czegoś, czego efektem jest dostrzeżona zmiana, ale raczej o kontrastowe zestawienie ze sobą biegunów dostrzeżonych zmian, na zasadzie: tak było... a tak jest teraz.
} 
z wielu perspektyw - by ją zrozumieć, wymaga raczej konceptualizacji będącej w stanie wydobyć jej heurystyczny potencjał. W celu zrozumienia wypowiedzi asystentów stosowano pojęcia pozwalające na odkrywanie znaczeń nieoczywistych, pozwalających na holistyczne ujmowanie aktywności profesjonalnej i spoglądanie na nią przez pryzmat procesu transformacji. Konceptualizacja toczyła się z pewnego, przyjętego punktu widzenia 5 .

\section{Modyfikacje tendencji aktywności korzystania z informacji o rodzinach}

Kiedy mowa o tendencji aktywności, to chodzi o związek pomiędzy podmiotem działającym i jego zaangażowaniem w aktywność (Barbier 2016: 223). Ów związek można rozumieć jako zmieniający się kierunek aktywności, któremu towarzyszą transformacje w obrębie organizowania aktywności (por. tamże: 146) oraz sposobów ich organizowania (por. tamże: 211). Jest to prawdopodobnie powiązane $\mathrm{z}$ transformacjami stosunku podmiotu do pola aktywności (por. tamże).

Asystenci w swoich wypowiedziach zwrócili uwagę na przemiany zachodzące w obrębie tendencji ich aktywności mentalnych, dyskursywnych i afektywnych, związanych z odczuwaniem. Ostatnie z wymienionych modyfikacji zostaną omówione w kolejnym paragrafie.

Asystenci unaocznili modyfikacje w obrębie ich tendencji do angażowania się w aktywności związane ze sposobami korzystania z informacji uzyskiwanych od rodzin lub na ich temat. Wypowiedzi asystentów wskazują na zmianę, jaką dostrzegają w procesie transformacji ich stosunku do tych informacji, co być może warto rozpatrywać jako modyfikację stosunków w czynie (tamże: 212-214).

Narratorka (A1) odniosła się do zjawiska mobilności funkcjonalnej (por. tamże: 81; głos J.-M. Barbiera, w: Kamińska-Jatczak 2019: 315). Informacje uzyskiwane od rodzin przestały mobilizować asystentkę do natychmiastowej reakcji, a zaczęły być przedmiotem weryfikacji.

Asystentka (A1): Wydaje mi się że może w tej chwili/ ${ }^{6}$ kiedyś powiedzmy był telefon i pani mi mówi, ona potrzebuje pomocy, czy smsa tak, bo mam taką panią która smsy pisze: - ona potrzebuje pomocy. I wie pani dla mnie nieważne, że to było Boże Narodzenie, święto, czy cokolwiek, ja po prostu zbierałam się i jechałam tak, bo

\footnotetext{
${ }^{5}$ Konceptualizacja, która służy interpretacji tekstu narracyjnego, natrafia na nie lada rafy, związane z chaosem aktywności, w którym uczestniczy podmiot działający. Chodzi o rozumienie chaosu jako metafory złożoności (por. Klus-Stańska 2010: 23), która uczula na ontologiczny chaos aktywności - jest zbyt wiele elementów, które trzeba zrozumieć i w pewien sposób ze sobą powiązać, co sprawia, że ma się wrażenie bałaganu, nadmiaru, bezładu, nie sposób bowiem wziąć pod uwagę wszystkich istotnych zagadnień. Dlatego interpretacja i konceptualizacja toczą się zawsze z jakiegoś ograniczonego punktu widzenia, który wydobywa chaotyczny porządek (por. LeCompte 1994: 280).

${ }^{6}$ Ukośniki zawarte w przywołanych fragmentach wywiadów symbolizują urwany tok wypowiedzi.
} 
moja pani potrzebuje pomocy. (...). Więc jak dostaję smsa od pani, to $w$ tej chwili co robię, ja go weryfikuję, tak. Ja do niej dzwonię, jeżeli się okazuje/bo to jest taka sprytna babka że ona wyłączy telefon. Więc ona ma nastoletnią córkę, dzwonię do córki, jeżeli się nie dodzwonię do córki, dzwonię do jej matki, która mieszka po sąsiedzku, więc staram się rzeczywiście dowiedzieć czy ta sytuacja wymaga mojego przyjazdu, tak. Bo ja też do pracy/ ja nie pracuję w swoim miejscu zamieszkania.

Jednocześnie informacje uzyskiwane od rodzin stały się dla asystentki (A1) istotnym składnikiem aktywności, który należy wziąć pod uwagę w procesie konstruowania celów działania. Narratorka wskazuje również na konteksty wskazanych zmian, które dotyczą: (1) związku stosunków między podmiotami, ustanawianych w toku określania celów działania, z ich wyodrębnieniem (por. Barbier 2016: 137), oraz (2) zmieniających się skłonności podmiotu do nadawania sensu realizowanej aktywności, które mogą wynikać z procesu nabywania i gromadzenia doświadczenia profesjonalnego.

Asystentka (A1): Wie pani na początku pisząc plan pracy to to wszystko było takie górnolotne że tak powiem, bo w książce było indywidualne podejście, wsparcie psychologiczne, tak. Ja na przykład w tej chwili unikam sformułowań, wsparcie psychologiczne, bo uważam, że skoro nie jestem psychologiem, to nie udzielę wsparcia psychologicznego, mogę udzielić wsparcia pedagogicznego, tak. Więc bardziej te cele/ może tak, więcej słucham też tych rodzin, czyli nie patrzę na to co kierownik mówi mi że trzeba w tej rodzinie zrobić, tylko bardziej słucham tego czego rzeczywiście ta rodzina chce, tak. I może to wynika też z tego, że później ta praca ma większy sens, bo jednak my idziemy małymi krokami.

Fragmenty wypowiedzi asystentki (A1) wskazują na modyfikację tendencji konstruowania informacji na temat rodzin, a także sposobów weryfikowania tych informacji. Tego rodzaju modyfikacja, dostrzeżona przez asystentkę, wynika z procesu kumulowania doświadczenia profesjonalnego w obrębie konstruowania informacji na temat rodzin, w którym rozwija się splot logik charakteryzujący specyfikę indywidualnego rozumowania (por. Kamińska-Jatczak 2016).

Asystenci rozwijają między innymi logikę weryfikowania informacji, która pozwala im wydawać osądy związane z wartością uzyskiwanych komunikatów. Owa wartość może być powiązana $\mathrm{z}$ oceną komunikatów pod względem występowania zjawisk komunikacyjnych, takich jak: pomijanie, zafałszowywanie, wyolbrzymianie czy przejaskrawianie pewnych zdarzeń. Weryfikowanie przekazów komunikacyjnych uzyskiwanych od rodzin bywa zainicjowane w momentach aktywności wywołujących podejrzenie podmiotu, kiedy istotne dla niego staje się wyjaśnianie przebiegu zdarzeń poprzez weryfikację uzyskanych informacji.

W przypadku asystentki (A3) modyfikacja tendencji do korzystania z informacji uzyskiwanych od rodzin została powiązana ze zmianami jej zaangażowania w konstruowanie relacji między podmiotami (por. Barbier 2016: 190) opartych na 
zaufaniu ${ }^{7}$. Asystentka zachodzące zmiany sytuuje na osi zróżnicowanych biegunów: byłam ufna - teraz jest dystans.

Asystentka (A3): Na pewno podejście do ludzi. No podejście do ludzi. Że, powiem tak, że byłam bardzo ufna ludziom, wierzyłam i tak dalej. Teraz jest na pewno ten dystans. Jest dystans do tego, co mówią. Staram się, co zawsze lubiłam też obserwować ludzi, ich reakcje i ich gesty i tak dalej. I gdzieś tam, na tym punkcie jestem też wyczulona, że jak obserwuję ludzi, to ja już po prostu wiem, w którym momencie on mówi prawdę, w którym on, on kłamie. I tutaj na pewno się na tym punkcie już tego nauczyłam, w tej pracy, przez te trzy lata, że trzeba obserwować i być czujnym. No bo to jest podstawa. Nie można im do końca ufać, nie.

Wypowiedź asystentki skłania do refleksji nad zmieniającym się stosunkiem działającego do informacji uzyskiwanych od Drugiego, na którego on oddziałuje, w związku z procesem dojrzewania do profesjonalnego dystansu, który można rozumieć jako ustanawianie równowagi na linii napięcia ufność versus nieufność. Jest to napięcie istotne dla kondycji egzystencjalnej człowieka, które rzutuje na jego poziom otwartości wobec otoczenia i siebie samego już we wczesnym dzieciństwie (Witkowski 2015: 261-262) i może być także powiązane z naturalną tendencją do nawiązywania relacji społecznych, również w życiu profesjonalnym. W odniesieniu do praktyki pracy socjalnej napięcie ufność versus zdystansowana nieufność i umiejętne nim zarządzanie jest oceniane jako kompetencja profesjonalna, która rozwija się w procesie biograficznego stawania się profesjonalistą (np. Granosik 2002).

W przypadku logiki weryfikowania informacji asystent nie podchodzi podejrzliwie do wszystkich członków rodziny, lecz uruchamia podejrzliwe nastawienie poznawcze w sytuacjach rodzących przypuszczenia o byciu dezinformowanym. Podejrzenie stanowi punkt wyjścia do potwierdzenia lub podważenia przekazu informacyjnego rodziny w oparciu o dodatkowe informacje, uzyskane od innych. Nie należy jednak zapominać, że mentalne możliwości działającego, które łączą się z jego stosunkiem do informacji otrzymywanych od rodzin, mogą być również zdominowane przez podejrzliwy kontekst świadomości, w ramach którego rozpoznaje on środowiska rodziny i nadaje im sens. Chodzi o przypadek, kiedy działający explicite zakłada, że rodzina go dezinformuje, nie mając ku temu przesłanek popartych logiczną argumentacją ${ }^{8}$. Dynamika równoważenia napięcia między ufnością a dystansem powinna być brana pod uwagę w analizie transformacji procesu konstruowania i korzystania z informacji otrzymywanych od adresatów oddziaływania asystentów. Proces dojrzewania mentalnego do profesjonalnego dystansu,

\footnotetext{
7 W tym wypadku kategorię zaufania można traktować jako społeczny aspekt relacji, który może być aktywnie kształtowany przez różne podmioty (por. Mayer, Davis, Schoorman 1995: 712).

8 Wypowiadam się, sięgając do pamięci obserwowanych zdarzeń, z perspektywy uczestniczki w środowisku asystentów rodziny, w którym przebywałam jako praktyk przez kilka lat.
} 
w którym utrzymuje się zrównoważone napięcie między ufnością a dystansem, może ulec zdeformowaniu do postaci przeciwstawnej, w przypadku kiedy zdestabilizowana zostaje ta dynamiczna równowaga.

\section{Modyfikacje odczuwania aktywności oddziaływania na rodziny}

Kiedy mowa o odczuwaniu, to chodzi o percepcję/poznawanie zjawisk psychicznych, których doświadcza podmiot działający. Działający uświadamia sobie, postrzega, czyli poznaje swoje pobudzenia afektywne poprzez nastroje, impulsy, odczucia siebie w aktywności (Barbier 2016: 42, 160). Podmiot odczuwa aktywność, w której jest zanurzony, kiedy postrzega afekty i transformacje siebie pojawiające się przy okazji podejmowania aktywności (tamże: 130). Odczuwanie swojego istnienia i postrzeganie siebie są to procesy nieodłącznie związane z aktywnością (tamże). Ich obecność zaznacza się w tworzeniu związków, jakie podmiot konstruuje odnośnie do poznawanych afektów z transformacjami siebie (tamże).

Asystenci w swoich wypowiedziach wskazują na zmiany w odczuwaniu aktywności profesjonalnej, które są powiązane $\mathrm{z}$ procesem redefiniowania sensu nadawanego aktywności.

Asystentka (A1): Powiem pani, troszkę się uodporniłam na pewne rzeczy, bo na początku wszystko przeżywałam bardzo, bardzo personalnie. Jak coś się działo w rodzinie, to obwiniałam siebie, że czegoś nie zrobiłam, coś zawaliłam i tak dalej.

Asystentka (A3): No powiem tak, że mój stosunek na początku no to był lęk. To był lęk przed tą pracą, lęk przed chodzeniem do ludzi, lęk jak mnie przyjmą, też, gdzie wiedziałam, że w niektórych środowiskach, gdzie był poprzedni asystent dochodziło/tak było chyba w dwóch środowiskach czy trzech, gdzie rodziny nie bardzo chciały tego asystenta, nie bardzo na poprzednią asystentkę no godziły się.

Ów dynamiczny proces konstruowania sensu tego, co się robi, przeżywa, o czym się myśli wydaje się być stymulowany w sytuacjach komunikacyjnych rozpoznawanych przez działającego jako przestrzenie skłaniające do refleksji nad własnym doświadczeniem profesjonalnym. Asystenci w swoich wypowiedziach wskazują na sytuacje komunikacyjne, które coś im uświadomiły, dały do myślenia, stały się bezpieczną przestrzenią do wyrażania własnych odczuć, w rezultacie zdynamizowały proces nadawania sensu złożonych przeżyć emocjonalnych występujących w aktywności oddziaływania na rodziny (por. O’Connor 2020: 652). Louise O’Connor zwraca uwagę na to, że w praktyce pracy socjalnej istotną rolę odgrywa tworzenie przestrzeni, w których pojawia się szansa na uznanie i oswajanie przeżyć emocjonalnych, takich jak: strach, rozpacz, radość, współczucie, które współtworzą 
sens nadawany procesowi oddziaływania na rodziny i rzutują na poziom napięcia psychicznego odczuwanego przez działającego (tamże).

Badaczka (B): A mam jeszcze takie pytanie, bo to było dla mnie bardzo interesujące, bo pani wspomniała, że się pani uodporniła na pewne rzeczy. I chciałam zapytać czy może pani powiedzieć o tym trochę więcej, jak to się stało w ogóle, co spowodowało, że się pani uodporniła i jak w ogóle pani to rozumie, trochę rozwinąć ten wątek, bo to bardzo ciekawe.

Asystentka (A1): Właśnie wie pani co, chodzi też o to, że to za sprawą tego że/na pewno bardzo dużo dały mi szkolenia. Ja korzystałam dużo ze szkoleń ROPSu (Regionalne Centrum Polityki Społecznej), ze szkoleń darmowych, ze szkoleń online, gdzie robiłam je sama. To oczywiście czuję potrzebę szkolenia się. To może też wynikało z tego, że zaczęłam rozmawiać z innymi asystentami, jak wygląda ich praca i tak dalej i tak dalej. No i często oni mówili: - słuchaj, nie daj się też wkręcać ludziom w pewne rzeczy, tak. Bo oni to będą wykorzystywać, tak. Bo są też tacy ludzie, mówi, że będą ci dzwonić w nocy, o północy i będą wykorzystywać. (...)

Jak się uodporniłam? Powiem pani, że to chyba/ może nie, usłyszałam kiedyś od mojej córki takie zdanie, moja córka ma pięć lat i ona się mnie pyta: - a mamo a dla mnie kiedy będziesz miała czas? Może to też wynikało z tego, że dzieci mnie chyba uświadomiły, że się bardziej angażuję, że tak powiem w opiekę nad cudzymi dziećmi, a zapominałam o tym, że mam swoje dzieci, tak.

Asystentka (A1): Kiedyś korzystałam, ale to sama prywatnie z superwizji i uważam że to są rzeczy, które są asystentom ogromnie, ogromnie potrzebne, tak. Czyli takie spojrzenie, że tak powiem osoby, która nie siedzi w tym, tak, albo jest teoretykiem, albo siedzi w tym głębiej, jest w tym więcej, żeby powiedziała: - słuchaj, ale wiesz, takie niektóre rzeczy można odpuścić, można to załatwić inaczej.

Każdy podmiot odczuwa to, czego doświadcza, to znaczy, że zyskuje świadomość afektów i transformacji siebie, przekształca je w przedmiot swojej aktywności, zaczyna je poznawać i tym samym, poprzez swoją percepcję, przekształca świat, który postrzega - zmienia percepcję aktywności i samego siebie jako podmiotu działającego (por. Barbier 2016: 159-161). Z perspektywy transwersalnej analizy aktywności, odczuwanie siebie jest uświadamianiem sobie swoich pobudzeń afektywnych i jest to zarazem doświadczanie ich wpływu na proces nadawania sensu własnemu doświadczeniu (por. tamże: 204). Z tego punktu widzenia istotne w środowisku profesjonalnym wydaje się aranżowanie przestrzeni, które sprzyjają komunikacji o przeżywanym doświadczeniu profesjonalnym. Brak takich przestrzeni może powodować poczucie osamotnienia, opuszczenia u działającego.

Asystentka (A1): Jak coś się działo w rodzinie, to obwiniałam siebie, że czegoś nie zrobiłam, coś zawaliłam i tak dalej. Później zauważyłam że/ to znaczy może to wynikało z tego osamotnienia takiego. Później zauważyłam, że niestety nie mogę 
pozwolić na to żebym była sama, tak. Ja muszę żądać od pracownika socjalnego od innych służb żeby oni mi pomagali.

Asystent (A2): Jako że tak naprawdę pozostaję w większości przypadków, bo nie mówię, że we wszystkim, ale w większości przypadków jako samotny żeglarz w tym środowisku.

Osamotnienie, o którym wspominają asystenci, można interpretować jako ekspresję poczucia braku, deficytu impulsów w środowisku profesjonalnym, wspomagających proces pracy nad doświadczeniem, który pozwala konstruować i rekonstruować sens odczuwanej aktywności. Przy czym pracę nad doświadczeniem realizowaną przez praktyków pracy socjalnej - asystentów rodziny warto rozważać w związku z procesami obniżania, odreagowywania napięcia psychicznego, poszukiwania zrozumienia dla przeżywanych trudności. Substytutem dla zaspokojenia potrzeby wsparcia procesu pracy nad doświadczeniem profesjonalnym może stać się sfera prywatna, na przykład środowisko rodzinne, co w skrajnych przypadkach niekiedy doprowadza do „zatrucia całej biografii sferą zawodową” (por. Granosik 2006: 157). Takie zagrożenie, w przypadku praktyków pracy socjalnej, wydaje się realne $\mathrm{z}$ uwagi na proces pamięci aktywności (Barbier: 148), który zachodzi w kontekście aktywności mentalnej działającego będącego uczestnikiem zdarzeń z życia rodzinnego niekiedy związanych z intensywnymi emocjami, punktami zwrotnymi, kryzysowymi, mozołem „wychodzenia czy też grzęźnięcia w życiowym bagnie”. Działający jest jednocześnie uczestnikiem życia rodzinnego, który sytuowany jest na pozycji profesjonalnej, powiązanej z oczekiwaniami społecznymi, by „coś zmienił, co można uznać za dostrzegalny efekt” 9 . Te społeczne oczekiwania implikują wysiłek asystentki (A3), by zrozumieć sytuację rodziny i znaleźć dla niej rozwiązanie.

Asystentka (A1): I powiem pani tak, jak zaczęłam pracę jako asystent, to ta praca (namysł) boże jakby to powiedzieć, ja nie umiałam rozmawiać o niczym innym, tylko o pracy, tak powiem. Ta praca absorbowała mnie całkowicie, więc ja wracając do domu roztrząsałam problemy tych ludzi i cały czas tylko tym żyłam, tak, w jakiś sposób.

Asystentka (A3): Ale to taki minus, bo człowiek przyjdzie do domu/ czasem naprawdę mam takie weekendy że po prostu siedzę nie raz i tak myślę, co by tam można było zmienić, co jeszcze można zrobić. I to jest też taka praca od której się nie można, na pewno nie można się odciąć. To się nie da.

\footnotetext{
${ }^{9}$ Fragment narracji asystentki (A1): I pamiętam po moich dwóch miesiącach pracy, kiedy spotkałam się z panią pedagog i akurat zjechałyśmy się z panią kurator w jednym czasie do szkoły. I pani pedagog taki zarzut w stosunku do asystenta mówi tak: - no widzi pani, pani kurator, nic się nie zmienia, asystent pracuje dwa miesiące i nie widać efektów, tak. Na co pani kurator mówi do niej: - no widzi pani, szkoła pracuje sześć lat i nie widać efektów.
} 
Aspektem wspomnianej pamięci aktywności jest pamięć emocjonalna, którą Konstanty Stanisławski zdefiniował poprzez przykład:

Dwóch podróżnych zaskoczył na skale przypływ morski. Uratowali się i dzielili później swymi wrażeniami. Jeden zachował w swej pamięci każdą poszczególną czynność: jak, dokąd, dlaczego poszedł, w jakim miejscu zszedł na dół, jak stąpał, gdzie skoczył. Drugi nic prawie nie pamiętał z tych szczegółów, utrwaliły mu się w pamięci tylko doznane wtedy uczucia10: z początku zachwyt, potem zorientowanie się w niebezpieczeństwie, niepokój, nadzieja, zwątpienie, wreszcie panika (Stanisławski 1953: 210).

Warto podkreślić, że Stanisławski zwracał uwagę na celowe, intencjonalne przywoływanie minionych zdarzeń i związanych z nimi emocji, następnie wykorzystywanych w konstruowaniu aktywności aktorskiej. Natomiast asystenci zmagają się raczej $\mathrm{z}$ trudnościami związanymi $\mathrm{z}$ odwrotnym wektorem tego zjawiska - z nasileniem pamięci emocjonalnej, kiedy odczuwalne są trudności związane z powstrzymywaniem się od przywoływania minionych zdarzeń z wizyt w rodzinach, co niesie ze sobą dalsze pobudzenie afektywne działającego.

\section{Modyfikacje interakcyjnej dynamiki odmowy uznania podmiotu działającego}

Asystenci w swoich wypowiedziach odnosili się do interakcyjnych epizodów aktywności z udziałem przełożonych i pracowników socjalnych, w których: (1) inny kierował ich zaangażowaniem $\mathrm{w}$ proces aktywności, w sposób niezgodny z ich intencją, który wzbudzał ich sprzeciw, (2) inny wyraził kwalifikację ich aktywności poprzez środki ekspresji pozwalające nadać jej znaczenie dyskredytujące, (3) odczuli sprzeciw związany z przebiegiem aktywności innego działającego. Te wszystkie epizody aktywności można interpretować z perspektywy procesu intersubiektywnych przestrzeni transformacji dynamiki odmowy uznania.

Odczucie odmowy uznania dla realizowanych aktywności profesjonalnych może być związane $\mathrm{z}$ interakcyjnym przebiegiem konwersacji, w którym ujawnia się estetyczny wymiar ekspresji. Dotyczy on wyrazistości aktywności wyrażanej poprzez środki ekspresji, za pomocą których podmiot działający odsłania to, co

\footnotetext{
${ }^{10}$ Przywoływany autor nie wprowadza rozróżnienia na uczucia i emocje (Barbier 2016). Emocje wskazują na momenty aktywności, w których pewien rytm i tryb zostają przerwane i/lub zawieszone, co sprawia, że podmiot na nowo musi określić swoje miejsce w nurcie aktywności, zrozumieć to, co mu się zdarza (tamże: 70-73). Natomiast uczucia wynikają z utrwalonych konstrukcji mentalnych, jakie podmiot tworzy o sobie, swojej aktywności, a także o relacjach, jakie tworzy z innymi (tamże: 235-236). W ramach przywołanego kontekstu pojęciowego w powyższym cytacie należałoby raczej mówić o emocjach.
} 
mentalne. Tutaj właściwie wkraczamy w świat drobnych gestów, symboli pozawerbalnego oddziaływania, ale także emocjonalnego zabarwienia wypowiadanych słów, których znaczenie jest od niego zależne. Ten estetyczny wymiar aktywności, związany z jej wyrazistością (por. Elzenberg 1999: 51-52), stwarza przestrzeń komunikacyjną, z perspektywy której działający odczytuje własną pozycję (por. Barbier 2016: 165) na tle stosunków między podmiotami w środowisku profesjonalnym ${ }^{11}$. Działający odczuwa deficyt uznania, kiedy spotyka się z szyderstwem, afrontem, poniżeniem. Tego rodzaju komunikaty współistnieją wraz z kwestionowaniem racjonalności podejmowanych działań, co szczególnie uwypuklił asystent (A2) w jednej ze swoich wypowiedzi:

Asystent (A2): Ja miałem troszeczkę, może niewielkie, ale szydercze uwagi dlaczego ja poszedłem do wójta i z jakiej racji w ogóle ja poszedłem do wójta prosić o przyspieszenie lub no w ogóle ingerowałem żeby jej wodę podłączono.

Odmowę uznania, jakiej doświadczają asystenci w interakcjach z innymi działającymi, można przeanalizować w odniesieniu do sfer uznania (por. Honneth 2012), takich jak: sfera bezpieczeństwa ontologicznego związana ze zrozumieniem, zaspokojeniem i dostrzeżeniem potrzeb rozwojowych jednostki (w kontekście działania profesjonalnego mogą to być potrzeby związane z poczuciem sprawstwa, autonomii, wolności w podejmowaniu decyzji) (por. Nowak-Dziemianowicz 2020: 81, 111); sfera prawa związana $\mathrm{z}$ przyznawaniem jednostce statusu moralnie odpowiedzialnego podmiotu sprawczego, który posiada kompetencje do wydawania sądów wartościujących (por. tamże: 82, 130), którą dalej będzie się określać sferą aksjologiczną.

Interakcyjną dynamikę odmowy uznania można określić jako epizody aktywności, które działający interpretuje jako sytuacje wartościujące, kwestionujące jakość jego zaangażowania w proces aktywności lub/i negatywnie waloryzujące jej wartość. Jest to sprzężone z odczuciem deprywacji potrzeb związanych z autonomią rozwijania aktywności profesjonalnej, co można wiązać (jak wskazuje przytaczany poniżej fragment wypowiedzi asystenta (A2)) z zaburzeniem instynktu aktywności (mocą aktywności, jej natężeniem afektywnym, jej kontynuacją bądź przerwaniem) (por. Barbier 2016: 88). Tego rodzaju sytuacje wpływają na transformację organizacji aktywności podmiotu, a nawet jej orientację.

Asystent (A2): Miałem bardzo niemiłą/ bo teraz mi się przypomniało jeszcze, bardzo niemiłą rozmowę z kierownikiem, kiedy to $\mathrm{w}$ tej wielodzietnej rodzinie, o której wspominałem wcześniej, najstarsza córka została zmotywowana przeze mnie po ukończeniu szkoły. (...) Dużo trzeba było pomagać, bo nie miała znikąd

\footnotetext{
${ }^{11}$ Asystentka (A1): „Ja nie mogę pójść do wójta, do burmistrza. To w ogóle asystent? Jak to/nawet nie powiem/ chodzi o to że jestem tak nisko na drabinie tej na szczeblu tym w pracy że jak śmiałabym pójść do burmistrza na rozmowę".
} 
pomocy. Szczególnie przed egzaminami, czy w jakimś przygotowaniu do jakiegoś kolokwium. Zostałem opierniczony przez przełożoną, że to jest człowiek, który ma 19 lat i dlaczego ja piszę w notatkach, że ja poświęciłem godzinę na rozmowę z matką, a godzinę na wsparcie Sylwii. Mówi - to już jest dorosła osoba. Ty nie masz prawa tego w asystenturze robić. - Ok - mówię - jesteś moim zwierzchnikiem, ok, dobra. Więc robiłem to poza asystenturą. Nie wydaje się pani? Znaczy to już pytanie retoryczne, że to większości asystentów by bardzo podcięło skrzydła. Zamiast wzmocnić - słuchaj/ nawet ja bym nie miał nic przeciwko temu, gdybym dostał taki komunikat - wiesz co X (imię narratora), ale może nie pisz o tym, może/ albo rób to poza godzinami spotkań z rodziną. Pomagaj tej dziewczynie. Nie, tu jest jasny, prosty komunikat - dlaczego ja to piszę i ja nie mam prawa tego robić. No i wie pani, ale ze względu może na to, że ja już mam trochę lat (śmiech), no mam trochę inne postrzeganie powiedzmy takich/otrzymywania takich komunikatów i powiedzmy gdzieś tam/ chociaż nie powiem, że gdzieś wewnątrz mnie nie pozostają/ nie pozostaje jakaś doza niesmaku, zniechęcenia, wiele razy. A mówię - rzucę to w diabły, bo nie będę się/ tylko że z tego co ja wiem i pracowałem również jako wychowawca i pedagog w OHP (ochotniczy hufiec pracy), to ja wiem, że nigdzie miodu nie ma, że każdy jest gdzieś tam nastawiony na piękne sprawozdania i jak to fajnie firma działa, a realne problemy są gdzieś tam zamiatane pod dywan.

Asystenci wyrazili deficyt potrzeby uznania ich autonomii konstruowania aktywności (indywidualnych sposobów i linii oddziaływania na rodziny), a także racjonalności z nimi związanych, na co wskazują poniższe wypowiedzi:

Asystentka (A1): A znowuż w tej pracy jest tak, że ja pisząc co robię w pracy, pani kierownik przychodzi do mnie i mówi tak - nie no, nie może być tak napisane, proszę to zmienić, bo to jest źle napisane. Więc moje pytanie jest, no ale ja piszę to co robię, no. No to ja mam albo kłamać w papierach żeby one były piękne, albo mam napisać to, co robiłam. I tu mam taki, że tak powiem rozdźwięk, bo czasem wydaje mi się, przychodząc tutaj do pracy, że ja w ogóle nie znam pracy asystenta, że ja mam zupełnie inne pojęcie o pracy asystenta niż mój kierownik. To są zupełnie/ że tak powiem, nie stykamy się, tak. To są dwie różne ścieżki, którymi ciężko jest się złączyć, znaleźć punkt wspólny.

Asystentka (A1): Ale mam takiego pana, który sam wychowuje dzieci, jest bardzo/ to jest taki trochę Piotruś Pan. Jest bardzo, bardzo niesamodzielny, o tak powiem. I mówię tak: - to ja z nim pojadę po prostu. Spotkamy się tam, w tej miejscowości, tak, gdzie jest ten/ Ja z nim pójdę do psychologa, żeby mu pomóc się umówić. I moja pani kierownik twierdzi, że to nie jest zadanie asystenta. Bo moje zadanie kończy się w momencie przekazania numeru telefonu. No i tu jest ta nasza rozbieżność, bo ja uważam, że asystent jest od asystowania, tak. Bo często ci ludzie, dla nich pójście do urzędu to jest ogromna trauma. W ogóle pójście gdziekolwiek, tak. 
Dynamika odmowy uznania zachodzi również w sferze aksjologicznej, która jest rozpatrywana $\mathrm{w}$ odniesieniu do holistycznej i transwersalnej perspektywy rozumienia wartości, jaką wprowadza Ewa Marynowicz-Hetka (2019: 185-186). Przywołana autorka zwraca uwagę na rozumienie wartości związane z wyobrażeniem, jakie powstaje w relacji z sobą samym i z innymi (tamże: 185). Ten punkt widzenia pozwala zauważyć, że działający mentalnie odkrywa sens danej wartości w związku z aktywnościami innych podmiotów. Ten aspekt uobecnienia się sfery aksjologicznej w doświadczeniu asystentów jest reprezentowany w ich wypowiedziach. Narratorzy przywołują sytuacyjne epizody aktywności, w których doszło do odczuwalnego i uświadomionego przez nich zdynamizowania transformacji procesu odmowy aksjologicznego uznania, który toczy się w ich polu aktywności profesjonalnej. Dynamika tego procesu jest powiązana z odczuciem braku uznania dla racji podejmowanego działania lub też odczuciem niezgody na wyobrażone racje działania Drugiego. Istotne w tym względzie mogą być momenty aktywności, w których dochodzi do „doświadczania wartości poprzez zerwanie” (Lavelle 1950: 3; Zuziak 2012: 103), kiedy podmiot doświadcza wartości przez zaistnienie procesów emocjonalnych oraz wolitywnych (Zuziak 2012: 110). Te momenty aktywności dynamizują aksjologiczną sferę odmowy uznania, gdyż pozwalają osądzić daną wartość, nadać jej sens w odniesieniu do wydarzeń i kontekstów, w których dochodzi do poczucia zerwania, odczucia obcości, niezgody, odmowy uznania dla racji wyrażających wyobrażenie wartości. Można w tym wypadku mówić o interakcyjnej dynamice odmowy uznania, w której działający doświadcza zakwestionowania jego racji, jak i może zakwestionować racje Drugiego. Asystent (A2) podejmuje temat odmowy uznania w interakcji z Drugim w poniższej wypowiedzi, choć wątek ten transwersalnie przenika wszystkie fragmenty wypowiedzi narracyjnych asystentów zamieszczone w tym paragrafie.

Asystent (A2): Jeżeli od pracownika socjalnego otrzymuję, albo słyszę taki komunikat - że ja tę osobę będę dojeżdżać i zrobię wszystko żeby odebrać im dzieci - chodzi o rodzinę wielodzietną, no to dla mnie już/ Głównie w tym wypadku konkretnym, bo to jest konkretny wypadek, dla mnie tutaj już rola kierownika jest, no powiedzmy co najmniej patologiczna. No bo nie działa na kierownika takie coś jak przysłowiowe gnębienie rodziny. On przyklaskuje jeszcze temu. Wręcz twierdzi - odebrać dzieci, bo my już pięć czy siedem lat z tą kobietą walczymy, a ona wszy/ znaczy staramy/ to wszystko jest w pięknych słowach ujęte, że my staramy się jej pomóc i robimy to dla dobra dzieci. Staramy się ją zmobilizować do czegoś, a ona zawsze na ostatnią chwilę. A nie dać jej zasiłku i zobaczymy co zrobi wtedy. No chyba dla/może ja się mylę, ale dla mnie to nie jest podejście pracowników pomocowych. Pracowników którzy ze względu na swój zawód powinni przede wszystkim mieć na uwadze pomaganie, a nie dojeżdżanie rodziny. Dojechałam/ i jeszcze chodzi ten pracownik socjalny chodzi z głową podniesioną i mówi - dojechałam jej męża, teraz się wezmę za dojechanie jej i zrobię wszystko żeby odebrać dzieci. 
Nosz kurcze, no. No powiem pani szczerze, że tak fizycznie, po ludzku, no to nóż w kieszeni się mi otwierał wtedy. No jak może pracownik socjalny coś takiego powiedzieć. Gdzie w tym wszystkim jest podstawowa zasada pracy socjalnej, nie wspominając o art. 119 par. 2 Ustawy o pomocy społecznej.

Rozwijanie się interakcyjnej dynamiki odmowy uznania doprowadza do pojawienia się, narastania i eskalacji konfliktu między podmiotami usytuowanymi w polu praktyki, co zostało zobrazowane w narracji asystenta (A2). Następuje wtedy zderzenie, starcie interakcyjne ${ }^{12}$, które wyraża eskalację oporu wobec braku uznania w środowisku profesjonalnym. Kiedy konflikt jest taką formą oporu, uzasadnione wydaje się rozpatrywanie go w kategoriach walki o zachowanie pozytywnych reprezentacji tożsamościowych na temat samego siebie, kiedy bój toczy się nie tylko o racje dla podejmowanych działań, ale również o podtrzymanie pozytywnego samorozumienia, pozytywnej wiedzy o samym sobie, „będącej rezultatem intersubiektywnych relacji" (Nowak-Dziemianowicz 2020: 118). Tego rodzaju sytuację interakcyjnego konfliktu wywołanego brakiem uznania dla podejmowanych działań przytacza asystent (A2). Co ciekawe, narrator przywołuje epizod aktywności, w którym doszło do interakcyjnego starcia po tym, jak przedstawia swoją wcześniejszą biografię profesjonalną, w której nawiązuje do aktywności dających podstawę do waloryzacji jego przygotowania do zawodu asystenta, takich jak: udział w szkoleniach ${ }^{13}$, prace doradcze we współpracy z komisją sejmową, kontakt $\mathrm{z}$ uznanymi $\mathrm{w}$ środowisku asystentów osobami, mającymi status eksperta, zapoznawanie się z organizacją pracy asystentów w innych ośrodkach na terenie kraju, znajomość literatury fachowej i przepisów regulujących funkcjonowanie zawodu. Wszystko to, o czym wspomina narrator, stanowiło dla niego zasoby, z których konstruował wiedzę własną (por. Marynowicz-Hetka 2019: 327), będącą wiedzą profesjonalną, tworzoną w procesie stosowania jej w działaniu praktycznym (por. Urbaniak-Zając 2016: 59). Korzystanie z tych zasobów jest powiązane z przypisywaniem własnemu działaniu właściwości świadczących o kompetencjach (por. Barbier 2016: 98). Narrator walczy o uznanie wartości dla siebie jako podmiotu działającego w polu praktyki, co jest związane z konstruowaniem reprezentacji siebie (tożsamościowej) jako podmiotu aktywnego w tym działaniu (por. tamże: 192-194).

Asystent (A2): Więc mój jakiś kontakt z sejmową komisją ${ }^{14}$ się zakończył. W tym okresie naprawdę zapoznałem się, sam z własnej jakiejś tam woli, inicjatywy, ze wszystkimi opiniami z różnych ośrodków w Polsce. Ja sam osobiście rzeczywiście

\footnotetext{
${ }^{12}$ Etymologia słowa konflikt (confligõ - uderzać, ścierać się) (Aszyk 1998) wskazuje na momenty dynamizujące ten proces.

${ }^{13} \mathrm{Z}$ uwagi na obszerność wypowiedzi nie rozszerzam przytaczanego fragmentu narracyjnego o tamte zdarzenia, które przywołuje narrator.

${ }^{14}$ Narrator wspomina swoją współpracę z Komisją Polityki Społecznej i Rodziny działającą przy Sejmie RP.
} 
bardzo cenię panią Izę Krasiejko15 która zainicjowała może to też/ i jestem zwolennikiem jej częstochowskiej formy wypełniania tego zawodu. Później tam znajomości z Krakowem. Również wiele rozmów przeprowadziłem z panem Krzysztofem Sarzałą ${ }^{16}$, jeśli chodzi o trójmiasto, Gdańsk. Poznawałem inne ośrodki, inne metody pracy. Może nie tyle metody, tylko te drobne różnice pomiędzy różnymi ośrodkami. Na dzień dzisiejszy nie uważam że jestem ekspertem w dziedzinie asystentury rodziny, ale uważam, że no jakąś wiedzę mam. I przychodzi mi pracownik socjalny i ja się pytam - ok, dlaczego ty chcesz żebym ja tak robił? Mówię na jakiej podstawie, pokaż mi jakąkolwiek ustawową podstawę twojej wypowiedzi. Czy chociaż pokaż mi gdzie w podręcznikach, które/ czy w jakichkolwiek poradnikach asystenta rodziny jest to, o czym ty mówisz, że ja mam robić. Yyy argument jest jaki, no tu jest/ był zaskakujący dla mnie iii dla wszystkich byłby asystentów rodziny również. Otrzymuję odpowiedź: „Bo ja wiem jak inni asystenci pracują w innym ośrodku". No i jestem w szoku, oto wiedza, na podstawie której ktoś ocenia metody pracy asystenta nie mając podstawowej wiedzy na ten temat. Bo ja wiem jak inni asystenci pracują w innych ośrodkach. Ja mówię - poczekaj, ale ja przeciwko twojej wiedzy jak inni pracują w innych ośrodkach, ja mam coś innego. Ja mogę ci przynieść książkę, yy przynieść broszury, wskazać linki, materiały ze szkoleń gdzie jest opisane yyy jak asystent rodziny powinien pracować. No i zaczyna się powoli budować konflikt. Konflikt ten taki/ jeszcze raz muszę zaznaczyć, że konflikt ten jest podbudowywany pełną zgodą kierownika no i tutaj człowiek pozostaje, no nie wiem, jak jakiś Don Kichot walczący sam z wiatrakami.

Dynamika odmowy uznania w środowisku profesjonalnym doprowadza do deprywacji potrzeby uznania, co wyraża się poprzez aktywności kompensacyjne, obronne (por. Nowak-Dziemianowicz 2020: 96), a także unikowe. Przy czym, wymieniając cechy tych aktywności, nie chodzi o ich rozłączność, związaną z wyróżnieniem typów funkcjonalnych, ale o wskazanie ich oblicza związanego z transformacjami zachodzącymi w środowisku profesjonalnym. W przypadku asystenta (A2) wykształca się linia aktywności uniku, odgrodzenia się od świata ośrodka pomocy społecznej, którego profesjonalni uczestnicy stają się obcy, gdyż wyrażają racje działania wzbudzające niezgodę aksjologiczną.

Asystent (A2): Na zakończenie, jako puenta. Z roku na rok mam coraz więcej lat i to już jest moje rzeczywiście takie spostrzeżenie, że ja wolę przebywać z tymi ludźmi, niż z inteligentnymi ludźmi w ośrodku pomocy społecznej. (...) I niech mi pani wierzy, że staram się zrobić wszystko i uciec z tego ośrodka, wyjść, wyjść. Nie słuchać ich pierniczenia o podopiecznych. Yyy wolę posiedzieć nawet dłużej u ro-

\footnotetext{
15 Profesor szeroko znana gronu asystentów, między innymi za sprawą publikacji na temat metodyki pracy asystenta rodziny, prezes zarządu Ogólnopolskiego Stowarzyszenia Asystentów Rodziny (OSAR).

16 Pedagog, trener, wykładowca, specjalista przeciwdziałania przemocy w rodzinie. Autor standardów interwencji kryzysowej w pomocy społecznej oraz strategii interwencji w sytuacjach kryzysowych w szkole, obowiązujących w oświacie.
} 
dziny, niż w ośrodku pomocy społecznej. To jest taka moja puenta po siedmiu latach pracy, znaczy sześciu i pół roku pracy.

Dynamiczny proces konstruowania reprezentacji tożsamościowej o sobie jako podmiocie działającym w przypadku asystenta (A2) zachodzi w związku z brakiem przynależności do instytucji symbolicznej (por. Marynowicz-Hetka 2019: 320-321), jaka konstruuje się w środowisku profesjonalnym.

\section{Dyskusja na temat stylu komunikowania doświadczenia profesjonalnego}

Myślenie o aktywności profesjonalnej przez pryzmat paradygmatu transformacji pozwala określić styl komunikowania doświadczenia profesjonalnego jako wyraz doświadczania procesu transformacji związany z mówieniem o zjawiskach, które uznawane są przez podmiot za część tego procesu. Styl, o którym tutaj mowa, wskazuje na pewne cechy charakterystyczne (właściwości) powiązane ze sposobem, w jaki podmiot rozwija przekazywanie znaczeń na temat transformacji (por. Barbier 2016: 216).

Wypowiedzi o transformacji mieszczą się w obrębie kategorii doświadczenia komunikowanego (Barbier 2020: 228-229) i stanowią propozycję znaczeń nadawanych przez podmiot swej aktywności, która jest powiązana z konstrukcjami sensów tworzonych przez adresatów tych komunikatów (por. Marynowicz-Hetka 2018: 13). Interpretacja wypowiedzi asystentów zorientowana na odczytanie sensu tego, o czym mówią w związku z transformacjami zachodzącymi w ich życiu profesjonalnym, pozwala wyodrębnić styl komunikowania doświadczenia profesjonalnego.

Komunikacja asystentów dotyczyła transformacji zachodzących w obrębie tendencji aktywności oddziaływania na Drugiego, związanych z jej organizowaniem, odczuwaniem i nadawaniem jej sensu. Wypowiedzi asystentów były rozwijane poprzez wyodrębnienie dominanty wskazującej na dynamikę zachodzących zmian (Witkowski 2020). Asystenci wskazywali na czynniki dominujące, takie jak: zmieniający się stosunek do informacji od rodzin lub na ich temat, przekształcające się skłonności podmiotu do nadawania sensu realizowanej aktywności oddziaływania na Drugiego, zmiany zaangażowania w konstruowanie relacji między podmiotami w polu aktywności profesjonalnej, przeobrażenia w odczuwaniu aktywności oddziaływania na Drugiego. Bieguny przeobrażeń czy też translokacji tych czynników (por. tamże) można umiejscowić na osi wskazującej na jakość i intensywność zachodzących zmian wokół kategorii wskazujących na tropy epistemologii doświadczenia profesjonalnego (jego charakteru i specyfiki), takich jak: ufność - zdystansowanie, intensywne przeżywanie - uodpornienie, przynależność - osamotnienie, rzeczywistość - nierzeczywistość, autonomia - zależność, rozdźwięk/ rozbieżność - współbrzmienie/wspólność, współdziałanie - konflikt, uznanie - po- 
garda. Związki, jakie zachodzą między wymienionymi biegunami, były problematyzowane przez asystentów $\mathrm{w}$ zakresie radzenia sobie $\mathrm{z}$ napięciem wywołanym biegunowością zjawisk transformujących życie profesjonalne, co z kolei wywołuje dynamikę sprzężenia zwrotnego, które owo napięcie redukuje lub powiększa.

Asystenci komunikowali znaczenia związane z transformacją zachodzącą w ich życiu profesjonalnym poprzez odwoływanie się do epizodów aktywności interaktywnej, dynamizujących przebieg procesu transformacji. Ich komunikacja zawierała tropy aktywności związanych z dynamizowaniem procesu pracy nad doświadczeniem profesjonalnym i jego opracowywaniem oraz powiązanych z dynamizowaniem procesu odmowy uznania $\mathrm{w}$ środowisku profesjonalnym. Wypowiedzi asystentów wskazują na epizody, w których odkrywali subiektywne i społeczne oblicza podejmowanych aktywności (ich sens i wartość) oraz w których następowała modyfikacja orientacji ich aktywności (jej instynktu, kierunku i organizacji). Asystenci odnosili się do momentów aktywności zachodzących w toku relacji z Drugim, co wskazuje na relacyjność procesu konstruowania aktywności oddziaływania na rodziny.

\section{Konkluzja}

Proces doświadczania transformacji aktywności profesjonalnej oraz siebie jako podmiotu działającego jest związany z cechami ontologicznymi procesu transformacji, takimi jak: złożoność, powiązanie, symultaniczność, niewidoczność/bezszelestność (por. Marynowicz-Hetka 2018). Przekłada się to na sposób, w jaki podmiot uczestniczy $\mathrm{w}$ procesach transformacji życia profesjonalnego, w związku z jego obecnością w trzech wzajemnie powiązanych przestrzeniach psychospołecznych doświadczenia: przeżywania aktywności, opracowywania doświadczenia (konstruowanie reprezentacji mentalnych) i komunikowania o tym, czego doświadczono (por. Barbier 2020: 224-229; por. Marynowicz-Hetka 2019: 61-62). Innymi słowy, komunikowanie doświadczenia, którego tematem wywoławczym jest transformacja, przyjmuje swoistą postać i strukturę ze względu na dwie zasadnicze kwestie:

1) jest to aktywność będąca wyrazem określonego dynamicznego splotu aktywności, związanych z tym, co zdarza się podmiotowi, co on robi z tym, co mu się zdarza w związku z nadawaniem temu sensu i jakie propozycje znaczeniowe w powiązaniu z tym formułuje (tamże);

2) jest to aktywność, która przekazuje znaczenia dotyczące transformacji uświadomionych (najczęściej modyfikacji), przy całej złożoności procesów transformacyjnych, w których podmiot uczestniczy wybiórczo ${ }^{17}$.

\footnotetext{
${ }^{17}$ Podmiot nie dostrzega wszystkich złożonych powiązań procesów transformacji, które należy rozpatrywać jako strukturalnie pożenione i przebiegające symultanicznie. Dostrzega tylko te transformacje, których oczekuje, nie widzi ich efektów w odniesieniu do całości życia profesjonalnego, dostrzega jedne transformacje/modyfikacje, a pomija/nie dostrzega innych (por. Marynowicz-Hetka 2018: 15).
} 
Z tego punktu widzenia poznanie transformacji życia profesjonalnego wymaga wsparcia pozwalającego zdynamizować splot aktywności, których dostrzegalnym wyrazem staje się komunikowanie doświadczenia profesjonalnego. Tego rodzaju dynamika zachodzi, kiedy podmiot działający uzyska dostęp do złożoności procesów transformacji życia profesjonalnego, w których uczestniczy poprzez otwarcie drogi do doświadczenia, które samo nie przyszłoby mu do głowy (Witkowski 2020: 15). Narzędziem do pobudzenia tego złożonego procesu konstruowania doświadczenia transformacji życia profesjonalnego jest komunikacja prowadzona w oparciu o interpretację wypowiedzi podmiotu działającego. Może być ona punktem wyjścia do odczytania znaczeń, jakie płyną od działającego na temat jego doświadczenia profesjonalnego, po to, by następnie opowiedzieć mu o tym, co zostało zinterpretowane, odkryte, odnalezione w jego komunikacji. To wzajemne sprzężnie zwrotne - pomiędzy przekazywaniem znaczenia i nadawaniem mu sensu - wydaje się być sprzyjającą przestrzenią do tego, by pogłębiać namysł o doświadczanych transformacjach życia profesjonalnego. Ów namysł może zmierzać w stronę poszukiwania zrozumienia dla:

- złożoności dwubiegunowych relacji i napięć zachodzących pomiędzy kategoriami określającymi epistemologię doświadczenia profesjonalnego;

- przebiegu procesów transformacji, których widocznym efektem są uświadomione modyfikacje;

- zmieniających się zdolności/możliwości do równoważenia biegu procesów transformacji w stronę poszukiwania mechanizmów, za pomocą których się dokonują.

Taki zdwojony namysł nad komunikowanym doświadczeniem ma szansę stać się refleksją nad sobą samym jako podmiotem działającym, poszukującym uzasadnień dla preferencji orientacji działania we własnym doświadczeniu transformacji życia profesjonalnego.

\section{Bibliografia}

Aszyk P. SJ. (1998) Konflikty moralne a etyka, Kraków, Wydawnictwo WAM-Księża Jezuici.

Barbier J.-M. (2006) Działanie w kształceniu i pracy socjalnej. Analiza podejść, tłum. G. Karbowska, Kraków, Wydawnictwo Naukowe „Śląsk”, seria: Biblioteka Pracownika Socjalnego.

Barbier J.-M. (2015) Nowe wyzwania dla badań w naukach o wychowaniu: perspektywa działania/aktywności, tłum. G. Karbowska, konsultacja naukowa: E. Marynowicz-Hetka, „Nauki o Wychowaniu. Studia Interdyscyplinarne”, nr 1 (1), s. 60-72. 
Barbier J.-M. (2016) Leksykon analizy aktywności. Konceptualizacje zwyczajowych pojęć, tłum. i oprac. E. Marynowicz-Hetka, Łódź, Wydawnictwo Uniwersytetu Łódzkiego.

Barbier J.-M. (2020) Konstruowanie aktywności i podmiotu w aktywności - wzajemne powiq̨zania, tłum. G. Karbowska, konsultacja naukowa L. Witkowski w: Pedagogika społeczna. Spotkania, trwanie i zmienność, pogranicza, A. Walczak, L. Telka, M. Granosik (red.), Łódź, Wydawnictwo Uniwersytetu Łódzkiego, seria: Stała Konferencja Pedagogiki Społecznej pod patronatem Komitetu Nauk Pedagogicznych PAN, t. 10, s. 223-230.

Barbier J.-M., Durand M. (red.) (2018) w kooperacji z C. Cohen, M.-L. Vitali, Représenter/transformer. Débats en analyse des activités, Paris, L'Harmattan.

Elzenberg H. (1999) Ekspresja pozaestetyczna i estetyczna w: H. Elzenberg, Pisma estetyczne, oprac. i wstęp L. Hostyński, Lublin, Wydawnictwo Uniwersytetu Marii Curie-Skłodowskiej, s. 51-68.

Granosik M. (2002) Kształcenie - Tożsamość - Działanie. O biograficznym wymiarze pracy socjalnej w: Badanie - Działanie - Kształcenie. Czyli o przydatności dyscyplin społecznych dla doskonalenia praktyki profesji społecznych $w$ dziedzinie oświaty, kultury i pracy socjalnej, E. Marynowicz- Hetka (red.), Łódź, Łódzkie Towarzystwo Naukowe, s. 21-33.

Granosik M. (2006) Profesjonalny wymiar pracy socjalnej, Katowice, Wydawnictwo Naukowe „Śląsk”, seria: Biblioteka Pracownika Socjalnego.

Gülich E. (1984) Próba analizy tekstu narracyjnego z perspektywy teorii komunikacji: (na przykładzie ustnych i pisemnych wypowiedzi narracyjnych), tłum. M. Łukasiewicz, „Pamiętnik Literacki”, t. LXXV, z. 4, s. 249-285.

Honneth A. (2012) Walka o uznanie. Moralna gramatyka konfliktów społecznych, tłum. J. Duraj, t. XXII, Kraków, Zakład Wydawniczy „Nomos”, seria: Współczesne Teorie Socjologiczne.

Kamińska-Jatczak I. (2016) Logiki aktywności mentalnych asystentów rodziny - próba interpretacji w: Praca socjalna jako dyscyplina naukowa? Współczesne wyzwania wobec kształcenia i profesji, M. Kawińska, J. Kurtyka-Chałas (red.), Warszawa, Wydawnictwo Naukowe UKSW, s. 275-295.

Kamińska-Jatczak I. (2019) Myślq̨c o transformacjach: sympozjum naukowe (Łódź, 23.05.2019), „Nauki o Wychowaniu. Studia Interdyscyplinarne”, nr 1 (8), s. 312-323, https://doi.org/10.18778/2450-4491.08.23

Klus-Stańska D. (2010) Dydaktyka wobec chaosu pojęć i zdarzeń, Warszawa, Wydawnictwo Akademickie „Żak”. 
Lavelle L. (1950) Traité des valeurs, Paris, Les Presses Universitaires de France.

LeCompte M. D. (1994) Defining reality: applying double description and chaos theory to the practice of practice, "Educational Theory”, vol. 44 (3), s. 277-299, https://doi.org/10.1111/j.1741-5446.1994.00277.x

Marynowicz-Hetka E. (2018) Myśląc o życiu duchowym/mentalnym w kontekście aktywności: transformacje bezszelestne versus modyfikacje, „Studia z Teorii Wychowania", t. IX, nr 1 (22), s. 9-23, https://sztw.chat.edu.pl/resources/html/article/ details?id=174906 [dostęp: 12.07.2021].

Marynowicz-Hetka E. (2019) Pedagogika społeczna. Pojmowanie aktywności w polu praktyki, Łódź, Wydawnictwo Uniwersytetu Łódzkiego.

Mayer R. C., Davis J. H., Schoorman F. D. (1995) An integrative model of organizational trust, „The Academy of Management Review”, vol. 20 (3), s. 709-734, https://doi.org/10.2307/258792

Nowak-Dziemianowicz M. (2020) Szkoła jako przestrzeń uznania, Warszawa, Wydawnictwo Naukowe PWN.

O'Connor L. (2020) How social workers understand and use their emotions in practice: A thematic synthesis literature review, „Qualitative Social Work”, vol. 19 (4), s. 645662, https://doi.org/10.1177\%2F1473325019843991

Schütze F. (1977) Die technik des narrativen interviews in interaktionsfeldstudien - dargestellt an einem projekt zur erforschung von kommunalen machtstrukturen w: Arbeitsberichte und Forschungsmaterialien, Bielefeld, Universität Bielefeld, Fakultät für Soziologie, t. 1, s. 1-62.

Stanisławski K. (1953) Praca aktora nad sobq w twórczym procesie przeżywania, cz. 1, tłum. A. Męczyński, Warszawa, Państwowy Instytut Wydawniczy.

Ulatowska H. (2014) Narracje transformacyjne (quest narratives): Wizerunki afazji w: Studia z neuropsychologii klinicznej na 45-lecie pracy zawodowej profesor Danuty Kądzielawy, E. Łojek, A. Bolewska, H. Okuniewska (red.), Warszawa, Wydawnictwo Uniwersytetu Warszawskiego, s. 97-110, https://doi.org/10.31338/UW .9788323514442.PP.97-110

Urbaniak-Zając D. (2016) W poszukiwaniu teorii działania profesjonalnego pedagogów. Badania rekonstrukcyjne, Kraków, Oficyna Wydawnicza „Impuls”.

Witkowski L. (2015) Versus. O dwoistości strukturalnej faz rozwoju w ekologii cyklu życia psychodynamicznego modelu Erika H. Eriksona, Kraków, Oficyna Wydawnicza „Impuls”, Wyższa Szkoła Biznesu w Dąbrowie Górniczej. 
Witkowski L. (2020) Transformacje i ich dominanty: między dynamikq i strukturq procesualności, „Chowanna”, t. 2 (55), s. 1-22, https://doi.org/10.31261/CHOWANNA .2020 .55 .02

Zuziak W. (2012) Aksjologia Louisa Lavelle'a. Wobec ponowoczesnego kryzysu wartości, Kraków, Wydawnictwo WAM.

\section{Transformations of Child Protection Workers' Professional Life: Communicating Experiences}

\section{Summary}

The subject of the research was the experienced transformations of the professional life of child protection workers communicated in the form of a narrative. The result of this communication was the protection workers' statements about the process of changes taking place in their professional lives. Interpretation of the statements was carried out in order to understand what transformations the workers identify and in what style they communicate them.

The protection workers' statements were conceptualized in terms of identifying modifications to the processes of transforming professional life that they indicated. The workers highlighted modifications in: (i) the use of information obtained from or about families; (ii) perception of activity related to their feeling as a professional and giving it meaning; (iii) the non-recognition process for any action taken. Interpretation of the statements was done mainly in relation to Jean-Marie Barbier's concepts of the transversal analysis of activity. However, the text also echoes other positions: Axel Honneth and Mirosława Nowak-Dziemianowicz on the struggle for recognition, Ewa Marynowicz-Hetka on the holistic and transversal perspective of understanding values, and Konstanty Stanisławski on emotional memory.

As a result of the interpretation of the statements, the style of communicating professional experiences emerged. This style, firstly, is associated with the isolation of dominant factors, indicating the dynamics of changes taking place in the tendency to engage in the implementation and development of activities influencing the Other; and, secondly, by recalling specific episodes of activity. These episodes are related to the dynamization of the process of working on professional experience and its development, and to the dynamization of the process of refusing recognition for undertaken activities.

In conclusion, the possibility of stimulating the reflection of the acting subject is indicated by referring to the interpretation of professional experiences revealed in the process of communication addressed to the researcher. 


\section{Transformation de la vie professionnelle des assistants familiaux : communication des expériences}

\section{Résumé}

La recherche a porté sur les transformations vécues de la vie professionnelle des assistants familiaux, communiquées sous forme de récit. Nous avons recueilli des énoncés des assistants sur les processus en cours de transformation de leur vie professionnelle. L'interprétation des énoncés a permis de comprendre ces transformations identifiées par des assistants, et le style dans lequel elles sont communiquées.

Les énoncés ont été conceptualisés en termes d'identification des modifications signalées :

- utilisation des informations reçues de la part des familles ou sur celles-ci,

- perception (sentiments, éprouvés) par les professionnelles qui leur donnent un sens,

- non-reconnaissance de l' action entreprise.

L'interprétation des énoncés des assistants a été faite principalement en référence aux concepts de l'analyse transversale de l'activité de Jean-Marie Barbier. Cependant, d'autres positions sont également présentes : Axel Honneth et Mirosława Nowak-Dziemianowicz concernant la lutte pour la reconnaissance, Ewa Marynowicz-Hetka concernant la perspective holistique et transversale de la compréhension des valeurs, Konstanty Stanisławski concernant la mémoire émotionnelle.

À la suite de l'interprétation des énoncés des assistants nous avons vu émerger le style de communication des expériences professionnelles. Ce style est lié à la distinction des facteurs dominants, indiquant une dynamique de changement dans les tendances d'engagement d' activités auprès de l'autre.

Ce style est lié à des épisodes spécifiques de l'activité. Ces épisodes sont en lien avec la dynamisation du processus de travail sur l'expérience professionnelle, ainsi qu'à la dynamisation du processus de refus de reconnaissance des activités entreprises.

En conclusion, nous soulignons la possibilité de stimuler la réflexion du sujet agissant par référence à l'interprétation des expériences professionnelles révélées dans le processus de communication adressée au chercheur.

\section{Cytowanie}

Kamińska-Jatczak I. (2021) Transformacje życia profesjonalnego asystentów rodziny: komunikowanie doświadczeń, „Nauki o Wychowaniu. Studia Interdyscyplinarne” 2(13), 227-250, https://doi.org/10.18778/2450-4491.13.14 